\title{
IMMIGRANT NARRATIVES AND HYBRID IDENTITIES: ANALYZING AUTOBIOGRAPHICAL NARRATIVES WRITTEN BY IMMIGRANT STUDENTS \\ IN GREECE'
}

\section{NARRATIVAS E IDENTIDADES HÍBRIDAS DE IMIGRANTES: ANÁLISE DE NARRATIVAS AUTOBIOGRÁFICAS ESCRITAS POR ESTUDANTES IMIGRANTES NA GRÉCIA}

\section{Argiris Archakis}

\begin{abstract}
As one of the primary means for identity construction (see DE FINA, 2015), narrative has recently been examined in relation to immigrant and refugee movements. Having at our disposal elicited, written autobiographical narratives of immigrant students living in Greece, we investigate the identities they construct therein. Our sample consists of 118 essays collected from 8 different lyceums situated in different parts of the Peloponnese, Greece. The students who wrote the essays were bilingual immigrants of various origins (mostly from Albania).

The broader theoretical framework of our study is that of Critical Discourse Analysis. One of the most important research issues within Critical Discourse Analysis concerns the investigation of the relationship between the macro-level of dominant discourses and the micro-level of the individual (in the present case, narrative) positionings towards dominant discourses (see VAN DIJK, 2008). For the analysis of the narrative positionings of the immigrant students we employ the model of three dilemmas proposed by Bamberg (2011) in combination with the concept of face threat (BROWN and LEVINSON, 1987).

The analysis shows that the decision of some immigrant students to reveal their victimization, due to racist behaviors by majority people, constitutes a threat against the collective face of majority people. We support the claim that these immigrant students position themselves in a complex manner towards the national, xenophobic and homogenizing discourse by projecting themselves as victims and victimizers simultaneously, and thus constructing hybrid resistance identities.
\end{abstract}

Keywords: autobiographical narratives; hybrid identities; immigrant students in Greece.

\section{RESUMO}

Como um dos principais meios para a construção da identidade (ver DE FINA, 2015), a narrativa foi recentemente examinada em relação aos movimentos de imigrantes e refugiados.

\footnotetext{
* University of Patras, Grécia. archakis@upatras.gr Orcid: https://orcid.org/0000-0001-7542-9782

1. I would like to thank the two anonymous reviewers and my colleague Prof. V. Tsakona for their valuable comments.
} 
Tendo à nossa disposição narrativas autobiográficas eliciadas e escritas de estudantes imigrantes que vivem na Grécia, investigamos as identidades que aí constroem. Nossa amostra consiste em 118 ensaios coletados em 8 liceus diferentes situados em diferentes partes do Peloponeso, Grécia. Os alunos que escreveram as redações eram imigrantes bilíngues de várias origens (principalmente da Albânia).

O quadro teórico mais amplo de nosso estudo é o da Análise Crítica do Discurso. Uma das questões de pesquisa mais importantes dentro da Análise Crítica do Discurso diz respeito à investigação da relação entre o nível macro dos discursos dominantes e os posicionamentos do nível micro do indivíduo (no presente caso, narrativa) em relação aos discursos dominantes (ver VAN DIJK, 2008). Para a análise dos posicionamentos narrativos dos alunos imigrantes, utilizamos o modelo dos três dilemas proposto por Bamberg (2011) em combinação com o conceito de ameaça facial (BROWN e LEVINSON, 1987).

A análise mostra que a decisão de alguns estudantes imigrantes de revelar a sua vitimização devido a comportamentos racistas por parte de pessoas maioritárias, constitui uma ameaça à face coletiva da maioria. Apoiamos a afirmação de que esses alunos imigrantes se posicionam de forma complexa em relação ao discurso nacional, xenófobo e homogeneizante, projetando-se como vítimas e vitimizadores simultaneamente, construindo assim identidades híbridas de resistência.

Palavras-chave: narrativas autobiográficas; identidades híbridas; estudantes imigrantes na Grécia.

\section{INTRODUCTION}

As nation-states all over the globe have so far been the standard way of the institutional organization of a country, national mixtures are avoided, and the maintenance of national homogeneity is a continuous and persistent goal. Having this assumption as our starting point, this study focuses on the construction of hybrid identities by immigrant students in Greece. In the immigrant students' narratives at our disposal (section 2), we will analyze their narrative constructions of legitimizing identities and hybrid resistance identities (section 1.2.1). Focusing on the latter, we will highlight how the immigrant students of our sample attempt to strike a balance between the assimilating pressures they undergo, on the one hand, and their wish to maintain their diversity, on the other, within an ethnocentric (educational and social) environment, where diversity brings about racist reactions (see section 3).

The broader theoretical framework of this study is that of Critical Discourse Analysis, which investigates how social (racist, sexist, etc.) inequalities are (re) produced through discourse. Moreover, it highlights the forms of resistance against the naturalized perpetuation of social inequality through discourse (see VAN DIJK, 2008). Within this framework, we will discuss the directives of the dominant national, assimilative, and homogenizing discourse and the role of 
racism in pursuing homogenization (see sections $1,1.1 .1,1.1 .2$ ). We will focus on how immigrant students position themselves towards the dominant discourse constructing legitimizing identities and, in some cases, even hybrid resistance identities (see section 1.2.1). For this purpose, we will apply Bamberg's (2011) narrative model of three dilemmatic positionings so as to highlight the kind of agency through which the immigrant students narratively represent themselves or other immigrants, that is, whether or not they adjust themselves to the directives of the dominant discourse. We will, furthermore, exploit Brown and Levinson's (1987) concept of face threat (section 3). In the end, we will claim that, by revealing their victimization (due to majority racist behaviors against them) through specific narrative means (sections 1.2 .3 and 1.2.4), some immigrant students threaten the face of the majority victimizers, thus constructing hybrid resistance identities (sections 3 and 4 ).

\section{THEORETICAL FRAMEWORK: CRITICAL DISCOURSE ANALYSIS AND IDENTITY CONSTRUCTION}

Our research falls within the broader framework of Critical Discourse Analysis, which studies the discoursal reproduction of social inequalities at the expense of minority/immigrant groups (see VAN DIJK 2005, 2008). One of the most important research fields of Critical Discourse Analysis is the one that investigates the relationship between the macro-level, which concerns the dominant discourses, through which the representation and organization of social reality are attempted (see FAIRCLOUGH, 2003), and the micro-level, which includes the various (linguistic, communicative, semantic, etc.) positionings of the people towards the discourses of the macro-level (see VAN DIJK, 2008).

When it comes to the analysis of identities, a central distinction is that between the essentialist approach and the social constructionist approach. In the framework of the essentialist approach, discourse is not a constituent factor for forming identities. As a representative mirror, it depicts the innate and fixed characteristics of ourselves (BENWELL and STOKOE, 2006). On the contrary, in the framework of the social constructionist approach, discourse (in our case, narrative discourse) constitutes a means of positioning for people and, therefore, a way to construct their identities (BENWELL and STOKOE, 2006; BUCHOLTZ and HALL, 2003, 2005).

In this context, a basic assumption of our approach to the analysis of student identities in narratives is that, through their various linguistic and communicative 
choices, immigrant students position themselves towards the assimilative and homogenizing goals of the dominant national discourse. Through these positionings, the identity they wish to project emerges in a specific communicative setting (see BUCHOLTZ and HALL, 2005). Therefore, we approach identities not as a set of static and fixed internal characteristics of the students, but as an accomplishment of their discursive choices while building their narratives within a powerful framework of impositions and limitations (see ARCHAKIS and TSAKONA, 2012).

\subsection{Macro-level}

\subsubsection{National Homogenization and Racism: Two Facets of the Same Coin}

The national homogenizing discourse aims to delimit the nation and to present it as a pure entity with internal (linguistic and cultural) cohesion within the borders of a nation-state (see MOSCHONAS, 2005; BLOMMAERT and RAMPTON, 2011). As a result, western nation-states prevent their population from being mixed with languages and cultures different from the national ones. However, in the era of globalization, which has started since the mid-twentieth century, and after the deregulation of the powerful structures of the past (such as the collapse of the Eastern Bloc), migration, mainly to European countries, has immensely grown, and the moving populations (together with their languages and cultures) constitute 'problems' that need to be solved by the European sates (see BLOMMAERT and RAMPTON, 2011).

To prevent a possible mixture of populations, cultures, and languages, racist practices are often employed (see WODAK and RICHARDSON, 2013). Following van Dijk (2008, p. 103), we define racism as "constituted by social practices of discrimination (...) and relationships of power abuse by dominant groups, organizations and institutions." As a result, racism maintains the social inequalities between the majority and immigrant populations (VAN DIJK, 2005). Through racist behaviors, common differences (i.e. linguistic and cultural ones) between the majority and immigrant groups are perceived as weaknesses of the latter. Thus, the unequal treatment of immigrant groups, is not only maintained but also "justified" and "rationalized" to the extent that they do not align with majority norms (HANSON-EASY and AUGOUSTINOS, 2012, p. 29). As will be shown in the analysis of our narratives (section 3), immigrants are forced either to marginalization or to assimilation, and, thus, national homogeneity is maintained.

However, we should not overlook the fact that in the Western world racist attacks are usually covert and mild. This is due to the fact that the humanitarian and 
antiracist ideas for tolerating and accepting the "Others" and their difference are in social circulation in the Western, "civilized" world (see VAN DIJK, 1992). This will prove most useful for the analysis and interpretation of our data.

\subsubsection{The Discourse of Greek Xenophobic Homogenization}

We now turn our attention to how the national homogenizing discourse has affected the reception of immigrants during the twenty-year period 1990-2010 in Greece (see ARCHAKIS, 2018). The racist discourse concerning immigrants (coming from Albania and elsewhere) is based on the binary distinction between the "foreigners" and the national population. Illustrative are the metaphors used in public discourse to describe the "violent" disturbance of the linguocultural homogeneity of the majority population. For example, the arrival of immigrants at Greece has been metaphorically represented as an "invasion of immigrants"; it has also been suggested that Greek society has turned into an "unconfined space", an "endless mess full of Turco-Albanians and BulgaroPakis", since it is 'unbelievable' how easily "the "backdoors' open for the second and final fall of the Hellenism" (see BOUTOULOUSI, 2005). Through such representations of immigrants as existential threats against the national culture, the majority's wish to exclude them from the national body and from the respective civil rights is highlighted and naturalized (see LIAKOS, 2005, p. 101).

\subsection{Micro-level}

\subsubsection{Immigrant Identities}

At section 2.1.1. we pointed out that the possible mixture of the majority with immigrant populations might result in the subversion of the status quo at many levels, such as the socio-political, the cultural, the linguistic, etc. (see BLOMMAERT, 2010). Duchêne et al. (2013, p. 6) characteristically point out that:

[m] igration and the mobility of citizens (...) pose important challenges to the linguistic and cultural homogeneity that nation-states still rely on for defining their physical boundaries, their language and identity as well as the rights and obligations of their citizens.

To investigate the ways in which the immigrants might attempt to dispute (or not) national homogeneity, we initially exploit the distinction between legitimizing identities and resistance identities, which is proposed by Castells (2010). Legitimizing identities "are introduced by the dominant institutions of society to extend and rationalize their dominion vis à vis social actors" (CASTELLS, 2010, p. 8). We 
presume that they pertain to immigrants who are forced into linguistic, cultural, and social assimilation. Resistance identities "are generated by those actors who are in positions/conditions devalued and/or stigmatized by the logic of domination, thus building trenches of resistance and survival on the basis of principles different from, or opposite to, those permeating the institutions of society" (CASTELLS, 2010, p. 8). We detect resistance identities in immigrants with delinquent behaviors, when they try to survive as marginalized ethnic groups within a national territory by questioning its social conventions, norms, and hierarchies (see MARVAKIS, 2004).

However, beyond this polar distinction between legitimizing and resistance identities, we can detect more complex constructions. According to Bhabha (1994/2004), when people of different origins and social hierarchies, such as majority and immigrant populations, come into contact, the result is not necessarily the assimilation or the marginalization of the latter. A new "Third Space" might be created (BHABHA, 1994/2004, p. 53), a "cultural hybridity" (BHABHA, 1994/2004, p. 5), "an in-between reality" (BHABHA, 1994/2004, p. 19), which "disturbs the simple polarities or dualities" (BHABHA, 1994/2004, p. 76).

Hybridity, as defined by Bhabha (1994/2004), is a particularly useful concept which helps us account for the complex experiences of immigrant populations and the identities they construct. By applying this concept, we do not limit ourselves to the usual polar perception of immigrants, either as people excluded from society or as people in a "unidirectional process" of assimilation from their place of origin to the new place of residence. We can also perceive immigrants as trans-local and trans-national subjects, i.e. as people having experiences from various regions and cultures. In other words, we can perceive them as people who interact with the new environment of their (perhaps temporary) settlement, without necessarily having cut their bonds and relationships with their places of origin, and without having stopped traveling to those places - given the affordances offered by the social media and the modern means of transportation (see DE FINA, 2016). Due to immigrants' oscillation between different places, cultures and languages, their "in-between" experiences cannot easily be subsumed under already available categorizations, constructed by people who are permanently settled and lead a stable life (see BAYNHAM and DE FINA, 2017, pp. 32-33). Therefore, immigrants can be perceived as individuals with hybrid characteristics (see Bourdieu 1991 as quoted by Baynham and De Fina 2017, p. 38):

the immigrant is atopos, without place, displaced, unclassified (...). Neither a citizen nor foreigner, neither truly on the side of the Same, nor totally on the side of the Other, the "Immigrant" is located in this "bastard" place (...). 
Such a perspective highlights the in-between and ambiguous status that is typical of certain immigrants beyond their exclusion or their assimilation as a result of the dominance of national discourse (see section 1.1.1.). In other words, this perspective highlights the processes of constructing bybrid resistance identities (see ARCHAKIS, 2018), which, as Bhabha maintains (1994/2004, p. 159), lead to "the disavowal (...) of discriminatory identities that secure the 'pure' and original identity of authority." More specifically, Bhabha (1994/2004, pp. 157-8) points out that:

[r] esistance is not necessarily an oppositional act of political intention, nor is the simple negation or exclusion of the 'content' of another culture, as a difference once perceived. It is the effect of an ambivalence produced within the rules of recognition of dominating discourses (...).

Despite the xenophobic, racist perception of immigrants in 1990-2010 in Greece (see section 1.1.2), we would like to bring to the limelight identities of young immigrants who aim to follow personal and independent trajectories. Some of them overcome the polar distinction between the majority population and immigrant groups, thus forming hybrid identities which entail their connection not only with their homeland and their relatives, but also with Greece as a host country. Typical examples of such hybrid identities, as documented in relevant studies, are the following statements by young immigrants of Albanian origin: "Being an Albanian at heart and living in Greece" (PAPANDREOU, 2013, p. 209), "Practically, I belong here...Emotionally, I belong here and there" (MICHAIL and CHRISTOU, 2016, p. 7).

\subsubsection{Narrative and Immigration}

Further concentrating on the micro-level of analysis, we now present the analytical tools which will allow us to trace the positionings of the immigrant students of our sample towards the dominant national discourse and, subsequently, their identity construction processes.

We start with narrative as a textual mode of representing subsequent events through an evaluative perspective (LABOV, 1972). Narrative is recognized by many researchers "as a primary or fundamental genre" (GEORGAKOPOULOU, 2006, p. 33, see also ARCHAKIS1, 2014). More recent studies also highlight narrative as the "prime vehicle" for constructing identities (see DE FINA, 2015, p. 351). Taking into consideration immigrants' movements around the globe, narrative research focuses on immigrant narratives which emerge in various communicative 
circumstances and practices. In particular, research interest has turned its focus on narratives that might occur in everyday circumstances and practices (i.e. oral or on-line conversations), in institutional settings (i.e. asylum applications, interviews with the police authorities or job interviews) or in research settings (i.e. through interviews and focus groups) (see BAYNHAM and DE FINA, 2017). Elicited narratives are usually monologic, self-referential and autobiographical, while those occurring in institutional or everyday conversations are usually brief, fragmentary, and dependent on context and interlocutors practices (see BAYNHAM and DE FINA, 2017, DE FINA and TSENG, 2017). ${ }^{2}$ The issues directly or indirectly raised in these communicative circumstances concern the reason of immigration, the process of immigration and the (temporary or more permanent) settlement or resettlement, immigrants' relationship with their places of origin, the ways they are received and integrated in the new environments as well as the ways they interact therein (see BAYNHAM and DE FINA, 2017; DE FINA 2016; DE FINA and TSENG, 2017).

As we will discuss in detail in section 2, our data consists of elicited, written autobiographical narratives of immigrant students in Greece. These narratives function as identity texts, namely as texts which allow immigrant students to construct the identities they wish in relation to the cultural, linguistic, and other characteristics that, in their view, differentiate them from their majority classmates (CUMMINS, 2004; see also COHEN, 2008). In the essays we collected, immigrant students had the opportunity to selectively refer to the experiences of their immigration journey from their countries of origin to Greece, to the ways they were received by the majority population, as well as to the memories from their places of origin (see TSOKALIDOU, 2017).

\subsubsection{Bamberg's Model for the Narrative Identity Construction}

Exploring the affordances of narrative identity construction, Bamberg (2011) puts forward a model via which this constructive process takes place in relation to three dilemmatic positionings. The first dilemma concerns the constancy and change across time in the life of the represented characters. The second dilemma has to do with the projection of sameness versus difference, where we examine whether a character or a group of characters is classified together with or apart from other characters or other groups.

2. On the characteristics and functions of small stories, see Georgakopoulou (2007). 
The third dilemma concerns the agency of the represented characters, namely how they are positioned in relation to dominant discourses in social circulation. Here, we examine whether the characters are represented as aligning with the directives of the dominant discourses, thus their agency and initiative are low, or whether they are represented as diverging from these discourses, thus their agency and initiative are high. In other words, we concentrate on the 'tension' between the impositions entailed by the dominant discourses and the choices revealed via specific discourse practices (see also BAMBERG et al., 2011).

By applying Bamberg's model (2011) to our data, we observe the following: In immigrants' life there is a change, since they are forced (for various political, social, economic, or other reasons) to move from their countries to Greece. Immigrants' cultural and linguistic characteristics highlight their difference in relation to the Greek majority population. At this point, the question arises about the kind of agency and the way of handling their difference: Do they comply with the directives of the dominant national discourse (by constructing legitimizing identities) or do they attempt to resist against them by preserving aspects of their difference (by constructing forms of resistance identities)? Our working hypothesis is that, whereas most immigrant students of our sample comply with the directives of the national discourse, by constructing legitimizing identities, some attempt to threat the collective face of the majority in a mitigated manner by using specific discursive means in their narratives.

\subsubsection{Threatening the Positive Majority Face}

In order to analyze and highlight the threat against the face of the majority population detected in the written texts of some immigrant students of our sample, we will draw on aspects of politeness theory proposed by Brown and Levinson (1987).

According to Brown and Levinson's theory (1987), people aiming to show or build solidarity bonds with the members of a (dominant) group resort to positive politeness strategies which, among other things, evoke shared values, common ground, and the mutual appreciation between group members, and also show speakers' acceptance of common traits, wishes, aspirations, etc. (BROWN and LEVINSON, 1987).

On the contrary, when such strategies are not used or when negative comments about the group and/or its members are made (directly or indirectly), 
the latter's wish to be appreciated and cared for, namely their collective positive face, is threatened (see BROWN and LEVINSON, 1987, p. $66 \mathrm{ff}){ }^{3}$

In the analysis of our data (see section 3 ), we will show that through both the description of racist behaviors and the disclaimer I'm adjusting myself, but..., immigrant students threaten the collective majority face: They reveal actions which the majority should have avoided under the influence of Western humanitarian values. In both cases, the detected threat is reversed, as majority victimizers are transformed into the targets of their victims (i.e., immigrant students).

\section{THE DATA OF THE STUDY}

In the framework of the research program "Education for Foreign and Repatriate students", carried out under the auspices of the University of Thessaloniki and the Greek Ministry of Education, Greece, the research team of the University of Patras, Greece, visited about 50 schools (including primary schools, high schools and lyceums) in Attika and the Peloponnese, Greece, in April-October 2011. ${ }^{4}$ Its members distributed questionnaires with the aim to detect the attitudes of (majority and immigrant) students towards their heritage languages. Moreover, students were asked to produce a written essay and, more specifically, to enact the role of an imaginary immigrant friend of theirs and refer to the difficulties they face, as well as to whatever they like in the host country. We expected that immigrant students would choose to respond by drawing on their own experiences or on those of their parents and relatives.

In the following analysis, our attention focuses on the data collected from the lyceums of our sample and specifically from 8 lyceums (students' approximate age 16 to 18 years) of various towns in the area of the Peloponnese. In particular, we collected 118 essays in the form of autobiographical identity texts by bilingual immigrant students from both sexes coming from Albania, Armenia, Bulgaria, Moldavia, Poland, Romania, Russia and Ukraine. However, most of them came

3. As Sifianou and Bayraktaroğlu (2012) point out, face does not exclusively pertain to an individual, namely a specific speaker or recipient, but it might also refer to the collective face of a group of people (group-face). That is to say, it may refer to a social group, i.e. an ethnic group, it may exist out of the context of a specific interaction within which it is invoked and it may dynamically evolve as a socio-historical construction in time and through various social occasions (see also SPENCEROATEY, 2005; SIFIANOU, 2016; ARCHAKIS1; ARCHAKIS2, 2020).

4. The research team was set up within the framework of the action 5.1 of this program. The title of action 5.1 is the following: "Tracing the Needs for Reinforcing the Language of Origin of the Repatriated and Foreign Students." 
from Albania (approximately 60\%). ${ }^{5}$ Despite varying degrees of interference from their heritage languages, the language used by immigrant students both in the questionnaires and in the letters was the language used exclusively in Greek education, i.e. Standard Modern Greek.

Our research question mainly revolves around how immigrant students construct their identities in their autobiographical narratives by converging with the directives of the dominant national discourse or by diverging from them to some extent.

\section{DATA ANALYSIS}

Our analytical procedure is based on the following steps: We identified

1. expressions showing change in immigrants' lives and, in particular, their movement to Greece;

2. expressions showing immigrants' (cultural and linguistic) difference from majority people;

3. expressions showing immigrants' agency, in particular, whether they are represented as assimilated individuals, victims of racism or self-determining individuals which in our data means victimizers.

\subsection{From Legitimizing Identities to Hybrid Identities}

In most of the narratives of our sample (85\%), immigrant students avoid explicit descriptions of racist behaviors. On the contrary, in many essays they refer to their adjustment to the new place, as well as to the course they followed and the difficulties they faced, until they themselves and their families managed to adjust themselves to the host community. A representative example of the narratives of our sample is the following student narrative, in which the legitimizing identity of the represented immigrants is gradually constructed: their agency is low as it involves adjusting to the directives of the dominant national discourse:

(1) My dear friend,

When I came here I saw a different culture, the people seemed to me a little bit cold. My parents in the beginning had difficulty in finding a job and it

5. For further analysis of similar data in a larger sample, see ARCHAKIS1; ARCHAKIS2 (2020). 
was difficult for me to adjust at school, my classmates were a little bit distant and weird. Fortunately though my dear friend it wasn't too difficult to learn the Greek language, and my teachers helped me in that. they were really nice.

In the beginning things may have been a little bit hard, but as time went by I managed to adjust. Everything then seemed very different. I felt that I was in my own homeland, I made new friends with children that came also from different countries and had more or less the same experiences with me. My friends treat me very well and don't treat me with racism. My parents work and get paid very well. Our life here is very good. But I miss my homeland and my relatives so much.

While analyzing this autobiographical narrative (1), ${ }^{6}$ using the model of the three dilemmatic positionings by Bamberg (2011), we observe the following: A student of Albanian origin, enacting the role of a hypothetical friend of hers, refers to the change in her life because of immigration, which she represents as bringing about mild and not dramatic difficulties by using the mitigating modal verb may (In the beginning things may bave been a little bit bard). She emphasizes the fact that the sociocultural environment she encountered was different from her own (When I came bere I saw a different culture). Members of the majority keep her and her parents at a distance (the people seemed to me a little bit cold). More specifically, the student mentions that it was difficult for her to form relationships with the majority and adjust at school, and for her parents to find a job. This different social categorization because of her origin is overcome, when the student learns the Greek language and thus achieves linguistic assimilation. In other words, the student has a very good life, when she accepts the values of the host place and sees it as her own bomeland. Such adjustment allows her parents to find work with a good salary - which is usually the main reason for immigrating- and allows her to make friends with other immigrant and majority students, who now do not treat her with racism (My friends treat me very well and don't treat me with racism). This statement is most revealing as it implies that, until the student and her family learnt Greek and obviously accepted the dominant national values, namely until she eliminates her cultural diversity, her "friends" treated her in a racist manner.

To sum up, in this autobiographical narrative, the student is projected with an agency of adjustment to the directives of the dominant assimilative discourse and constructs a legitimizing identity throughout the whole narrative. However, it is worth highlighting the final part of this narrative: Our life bere is very good. But I miss

6. All the examples were translated into English by the author for the purpose of this article. Original Greek texts are omitted due to space limitations. 
my bomeland and my relatives so much. This extract presents a version of the general disclaimer I'm adjusting myself, but.... By using such disclaimers, which we will examine in more details in section 3.2.2, as well as by describing the racist attitudes they have encountered (see section 3.2.1), immigrant students attempt to diverge to some extent from the national directives by constructing identities of hybrid resistance, even in narratives where legitimizing identities prevail, as we saw in example (1).

\subsection{Hybrid Resistance Identities}

In this section we analyze narrative extracts in which the agency of the represented characters is still defined by the adjustment to national assimilative directives. The fact, however, that such agency is presented as a result of immigrants' victimization allows them to mildly threaten the collective majority face, thus constructing hybrid resistance identities.

\subsubsection{Racist Descriptions}

In our dataset, from the total of 118 essays only 18 of them (15\% of the 118 ) include references to racist behaviors. These 18 autobiographical narratives contain at least one instance of reference to racist behaviors. Assuming that most of the times narratives project the dominant social views, the fact that in our data the vast majority of the narratives examined (85\%) do not include explicit descriptions of racist behaviors shows the intense national homogenizing and assimilative pressure immigrant students undergo, as it has been pointed out by various ethnographic studies (see e.g. PAVLOU and CHRISTOPOULOS, 2004; PAPATAXIARCHIS, 2006). The classification of racist behaviors that follows will help us to account not only for the reasons why the vast majority of immigrant students are driven to choose low agency and the construction of legitimizing identities aligned with the dominant national discourse, but also for how some immigrant students construct hybrid resistance identities not fully aligned with the national discourse.

In our data, we distinguish three descriptive categories of racist behaviors (see ARCHAKIS, 2018). These behaviors obviously result from a sense of hierarchical superiority typical of majority populations when they are in social contact with immigrants. It seems that (at least some) majority people are reluctant to live in harmony with immigrants and to respect their personality. The descriptive categories of racist behaviors could be graded on the basis of the degree of the threat against the face of immigrant people, in the following way: 
- denigrating behaviors

- verbal insults

- excluding behaviors

These general categories form a continuum ranging from the description of relatively mild denigrating behaviors, to more threatening verbal insults, and finally to being deprived of any social contact with the majority:

a. Denigrating Behaviors

(1) Kids don't treat me that well because I'm not like them I don't belong to their country and I don't behave like them

(2) All teachers underestimated me and I had to prove that things are not the way they think they are

b. Verbal insults

(4) People laugh at you

(5) On the first day at school nobody wanted to sit next to me and they called me bad names

(6) Kids laughed at us (...) they swore at us using vulgar and bad words

(7) My classmates laughed at me saying things I don't want to tell you

(8) Every day at school I receive racist comments as far as I can understand of course

(9) Kids make fun of me and I feel bad

(10) Old women gossip about you behind your back; they say look at the Albanian

c. Excluding Behaviors

(11) At the beginning they were very close hearted and reserved, not for some particular reason but because we were from another country and they were afraid of us 
(12) Kids (...) didn't play with us and they kept us at a distance

(13) The first day at school nobody wanted to sit next to me

(14) Kids didn't like me and avoided me "as if I had done something wrong to them." They didn't even touch me

This classification includes three categories of racist behaviors (2-14). Using such descriptions, immigrant students are positioned towards the discourse of the national xenophobic homogeneity by projecting themselves with low agency, as victims of racist behaviors fostered by this discourse. The racist behaviors lead them -or rather force them- to accept the assimilative directives and adopt legitimizing identities (see example 1). What attests that they have been forced to construct assimilative legitimizing identities is the fact that the vast majority of the available essays do not include references to racist behaviors.

However, we believe that the choice of certain students to narrate their sufferings makes them not only victims, but also victimizers, and simultaneously divulges their effort to construct resistance identities, which, to some extent, diverge from the national directives. More specifically, given the fact that in the Western world, humanitarian and antiracist ideas about the acceptance of the "Other" are in social circulation, racist behaviors are not openly tolerated or, when they occur, are often covert or mild (see VAN DIJK, 1992). In this context, we can exploit Brown and Levinson's theory (1987), according to which, when the positive characteristics of a group are not projected or, on the contrary, when negative comments are made about this group (or its members), then their positive face is threatened. In our data, by revealing what the majority were not supposed to do in the framework of Western humanitarian values, immigrant students threaten the collective face of the Greek majority (see SPENCER-OATEY, 2005; SIFIANOU and BAYRAKTAROĞLU, 2012).

\subsubsection{The Disclaimer I'm Adjusting myself, but...}

In our data, we detected versions of the disclaimer I'm adjusting myself, but.... Through such disclaimers, immigrant students initially confirm their adjustment to the new place and evaluate it in a positive manner. However, immediately afterwards they partly mitigate this positioning. From the total of 118 student narratives, the disclaimer under scrutiny appeared in only 12 essays $(10,1 \%$ of 118$)$. These 12 autobiographical narratives contain at least one instance of a disclaimer. 
The scarcity of this disclaimer in our sample is also indicative of the intense homogenizing and assimilative effect of the national discourse, although in certain cases, like in narrative (1), the construction of legitimizing identities may coexist with the disclaimer under scrutiny.

In the examples that follow (see ARCHAKIS2, 2016), we examine the threat expressed in the second part of the disclaimer ${ }^{7}$ in combination with the positive attitude towards the Greek majority expressed in the first part of the disclaimer:

(15) In the beginning things may have been a little bit hard, but as time went by I managed to adjust. (...) My parents work and get paid very well. Our life here is very good. But I miss my bomeland and my relatives so much.

(16) Everything seems to me more familiar as the time goes by. But I will never stop missing my world... My world is there... A part of me is there...

(17) After almost a year I had got used to my second homeland [i.e. Greece]. I had also made many friends. I knew how to write and read and speak fluently the Greek language, everything seemed really easy bowever I never forget the hard days I bad at the beginning. At the moment I like Greece very much. I have many friends that I love very much, I am not treated in a racist manner at school (although sometimes I am) and that is why I'm really happy.

(18) The following year things went better and my schoolmates and my friends started to hang out with me. But [this bappened] after they bad heard that I was having psychological problems during the previous year.

In extracts 15-18, in the first part of the disclaimer, the effort to adjust to the host community is stated (in bold letters). Immigrant students thus attempt a positive self-presentation by showing their alignment with the national discourse: (gradual) acceptance of the terms of settlement and the values of the new place and, as a result, the creation of common ground with the majority. However, later on, the initial consent is partly revoked by expressions (in italics) introduced by contrastive markers such as but, however, although, nevertheless. In particular, in the second part, immigrant students reveal that, despite their effort to adjust, there is an explicit and intense gap in their family and social relations, which the new place does not bridge (examples 15-16). They also reveal their negative experiences in the host

7. In the extracts that follow, the second part of the disclaimer is marked in italics, whereas the first part is marked in bold. 
community, which constitute experiences of exclusion: great difficulty to become accepted, racist attitudes, psychological problems because of being rejected by classmates (examples 17-18).

The analysis so far reveals that the disclaimer under scrutiny consists of a consensual first part, where the gradual adjustment to the new place is stated, and a threatening second part. ${ }^{8}$ More specifically, in the second part, immigrant students reveal the emotional gap, which cannot be bridged by the conditions in the new place, and document their hard experiences because of the racist behaviors of exclusion they endured. Thus, they represent the majority population in a negative manner. As pointed out in section 3.2.1, when negative comments are made about a group or its members, then, according to Brown and Levinson (1987), their positive face is threatened. Via the disclaimer I'm adjusting myself, but... immigrant students perform mitigated threatening acts against the positive collective face of the majority: they reveal the alienation and the racism they experience, namely their victimization, which should have been avoided in the framework of Western humanitarian values (see also SPENCER-OATEY, 2005, SIFIANOU and BAYRAKTAROĞLU, 2012)

A key concept for a deeper analysis of the disclaimer I'm adjusting myself, but... is its intertextual connection with the disclaimer I'm not a racist, but..., which is often used by the majority populations. As Fairclough (1992, p. 84) points out, intertextuality concerns the "property texts have of being full of snatches of other texts, which may be either explicitly demarcated or merged in." He also notes the possibility of creating an intertextual chain, where some texts are transformed into others in a systematic way and with a visible in-between connection (see FAIRCOUGH, 1992, pp. 130-131).

As already pointed out, in the context of the humanitarian ideals of the tolerance and acceptance of the "Other" in the Western world, racist attitudes are usually expressed in a mild form and through disclaimers such I'm not a racist, but..., I bave notbing against the black people, but..., not everybody are criminals, but..., etc. van Dijk (1992), who has specifically analyzed these disclaimers, points out that they ensure, on the one hand, the "positive self-presentation" of the majority, aligned with humanitarian and "progressive" antiracist ideas and, on the other hand, they manage the negative presentation of specific behaviors of the immigrants mentioned in the second part of the disclaimer (i.e. they are dirty, they create trouble, they steal, they abuse the old people/the women/the children, they kill).

8. For a more detailed analysis of the graded threat included in the second part, see ARCHAKIS2 (2014). 
Between the two disclaimers there is a "manifest" intertextual link (see FAIRCLOUGH, 1992, p. 85), since both are based on the same structure consisting of a first part of positive self-presentation followed by a second part of negative other-presentation (see Figure 1):

1. [a. I' m not a racist, b. but...]

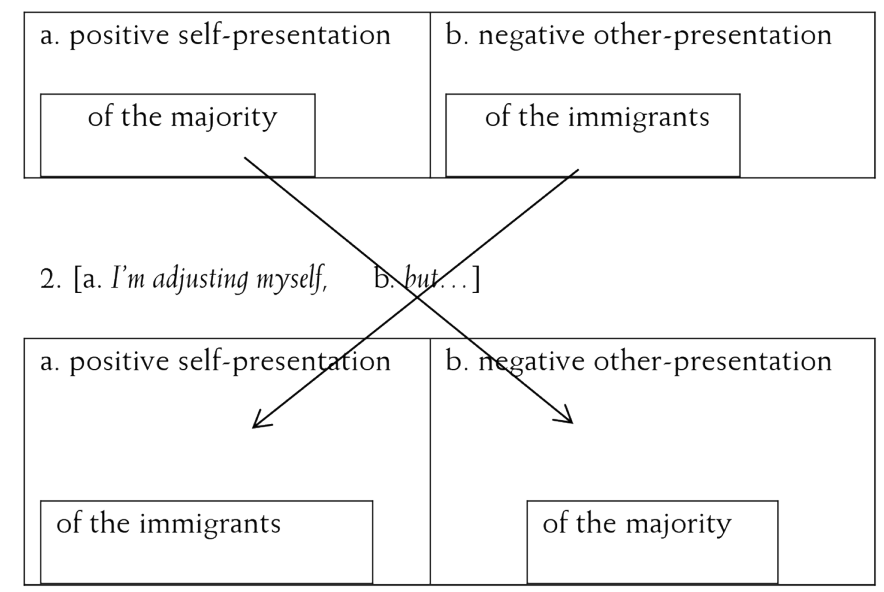

Figure 1. Intertextual links of the two disclaimers

Despite their structural similarity, the two scripts are different in their targets: The disclaimer I'm not a racist, but... includes a first part, where an antiracist attitude is initially stated by majority people and a second part, where majority people target and condemn certain acts and behaviors attributed exclusively to immigrants. The disclaimer I'm adjusting myself, but... presents a transposition of the parts and, consequently, a different target: it includes a first part, where immigrants state their consent and their compliance with the assimilative expectations. However, this compliance is partly revoked or mitigated, when in the second part the immigrant students state the shortcomings and the problems they face in the host country, directly or indirectly targeting their majority recipients. Therefore, we can assume that, by using the same oppositional structure, an intertextual chain is formed.

In sum, through the disclaimer I'm adjusting myself, but..., immigrant students construct in their autobiographical narratives identities, opposing the assimilative directives of the discourse of national homogeneity. They recontextualize the majority's disclaimer I'm not a racist, but... and reverse its target. However, the threat they attempt against the collective majority face is mild. Immigrant students 
first confirm their adjustment to the new place without, however, concealing their victimization which renders the disclaimer a threatening means. Their resistance identities thus emerge through a hybrid positioning.

\section{CONCLUSION}

Our study is carried out within the broader framework of Critical Discourse Analysis. More specifically, it focuses on the field that studies the interaction between the macro-level of the national, assimilative, and homogenizing discourse and the micro-level of the specific discoursal choices and positionings of the immigrant students of our sample. Having at our disposal autobiographical narratives by immigrant students in Greece, we paid particular attention to the kind of agency performed in relation to the directives of the dominant national discourse, through which immigrants represent themselves (BAMBERG, 2011). We also exploited the concept of face threat put forward by Brown and Levinson (1987).

Our findings suggest that in the vast majority of the autobiographical narratives of our sample, immigrant students avoid explicit descriptions of racist behaviors, while they often refer to their adjustment to the new place by choosing low agency and aligning with national discourse and, thus, constructing legitimizing identities.

In a limited number of narratives, however, we detected extracts which include racist descriptions as well as the disclaimer I'm adjusting myself, but.... We claimed that in these excerpts immigrant students construct hybrid resistance identities, which diverge from national expectations. By describing the racist behaviors of the majority, they present themselves both as victims who adjust themselves because of the racism they suffer from, and as victimizers because they reveal the racist acts of the majority. Additionally, with the disclaimer I'm adjusting myself, but... immigrant students reveal their adjustment to the host country without concealing their victimization, which renders the disclaimer a threatening means for the collective majority face.

The element of resistance in both processes of identity construction is revealed by using the concept of face threat as an analytical tool. More specifically, by describing the racist behaviors and through the disclaimer I'm adjusting myself, but..., immigrant students threaten the collective majority face, revealing acts that the majority populations should have avoided in the framework of Western humanitarian values. In both cases, the direction of the threat is reversed, and majority victimizers become the targets of their victims (i.e., immigrant students). 
In conclusion, it could be suggested that, when immigrant students represent themselves as adjusted to national expectations as a result of their victimization by the majority, namely when they reveal the racism they experience, they manage to threaten the collective majority face. Without being "neither truly on the side of the Same, nor totally on the side of the Other" (BOURDIEU, 1991, p. 9), they denounce the "discriminatory identities that secure the 'pure' and original identity of authority" (BHABHA, 1994/2004, p. 159). Thus, they construct hybrid resistance identities diverging from the directives and the expectations of Greek national discourse.

\section{REFERENCES}

ARCHAKIS, A.1 (2014). A Four-part Model for Narrative Genres and Identities: Evidence from Greek Data. Journal of Comparative Research in Anthropology and Sociology. v. 5, ${ }^{\circ} 1$, pp. 1-23.

ARCHAKIS, A.2 (2014). Immigrant Voices in Students' Essay Texts: Between Assimilation and Pride. Discourse and Society. v. 25, n ${ }^{\circ}$, pp. 297-314.

ARCHAKIS, A. (2016). National and Post-national Discourses and the Construction of Linguistic Identities by Students of Albanian Origin in Greece. Multilingual: Journal of Cross-Cultural and Interlanguage Communication. v. 35, $\mathrm{n}^{\circ}$ 1, pp. 57-83.

ARCHAKIS, A. (2018). The Representations of Racism in Immigrant Students' Essays in Greece: The 'Hybrid Balance' Between Legitimizing and Resistance Identities. Pragmatics. v. 28, nº 1 , pp. 1-28.

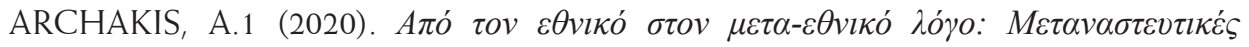
$\tau \alpha v \tau o ́ \tau \eta \tau \varepsilon \varsigma \kappa \alpha \iota ~ \kappa \rho \imath \tau \imath \kappa \eta ́ ~ \varepsilon \kappa \pi \alpha i ́ \delta \varepsilon v \sigma \eta$ [From the National to Post-national Discourse: Immigrant Identities and Critical Education]. Athens: Patakis.

ARCHAKIS, A.2 (2020). The Continuum of Identities in Immigrant Students' Narratives in Greece. Narrative Inquiry. https://benjamins.com/catalog/ni.19118.arc

ARCHAKIS, A. and TSAKONA, V. (2012). The Narrative Construction of Identities in Critical Education. Basingstoke: Palgrave Macmillan.

BAMBERG, M. (2011). Narrative Practice and Identity Navigation. In: Holstein, J. A. and Gubrium, J. F. (eds.), Varieties of Narrative Analysis. London: Sage, pp. 99-124. 
BAMBERG, M., DE FINA, A. and SCHIFFRIN, D. (2011). Discourse and Identity Construction. In: Schwartz, S. J., Luyckx, K. and Vignoles, V. L. (eds.), Handbook of Identity Theory and Research. New York: Springer, pp. 177-199.

BAYNHAM, M. and DE FINA, A. (2017). Narrative Analysis in Migrant and Transnational Contexts. In: Martin-Jones, M. and Martin, D. (eds.), Researching Multilingualism: Critical and Ethnograpbic Perspectives. London/New York: Routledge, pp. 31-45.

BENWELL, B. and STOKOE, E. (2006). Discourse and Identity. Edinburgh: Edinburgh University Press.

BHABHA, H. K. (1994/2004). The Location of Culture. London: Routledge.

BLOMMAERT, J. (2010). The Sociolinguistics of Globalization. Cambridge: Cambridge University Press.

BLOMMAERT, J. and RAMPTON, B. (2011). Language and Superdiversity. Diversities. v. $13, \mathrm{n}^{\circ} 2$, pp. $1-20$.

BOURDIEU, P. (1991). Préface. L'immigration ou les paradoxes de l'alterité by Abdelmalek Sayad. Brussels: De Boeck University.

BOUTOULOUSI, E. (2005). A in Journalistic Discourse]. Workshop of the Department of Journalism and Mass

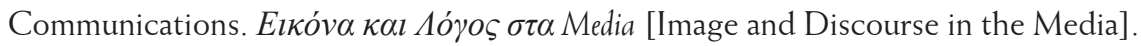
4.11.2005, Thessaloniki.

BROWN, P. and LEVINSON, S. C. (1987). Politeness: Some Universals in Language Usage. Cambridge: Cambridge University Press.

BUCHOLTZ, M. and HALL, K. (2003). Language and Identity. In: Duranti, A. (ed.), A Companion to Linguistic Antbropology. Oxford: Blackwell, pp. 368-394.

BUCHOLTZ, M. and HALL, K. (2005). Identity and Interaction: A Sociocultural Linguistic Approach. Discourse Studies. v. 7, n 4-5, pp. 584-614.

CASTELLS, M. (2010). The Power of Identity. 2nd edition. Malden: Wiley-Blackwell.

COHEN, S. (2008). Making Visible the Invisible: Dual Language Teacbing Practices in Monolingual Instructional Settings. Ph.D. thesis. University of Toronto, Canada. 
CUMMINS, J. (2004). Multiliteracies Pedagogy and the Role of Identity Texts. In: Leithwood, K., McAdie, P., Bascia, N. and Rodigue, A. (eds.), Teaching for Deep Understanding: Towards the Ontario Curriculum That We Need. Toronto: Corwin Press, pp. 68-74.

DE FINA, A. (2015). Narrative and Identities. In: De Fina, A. and Georgakopoulou, A. (eds.), The Handbook of Narrative Analysis. Chichester: Wiley Blackwell, pp. 351-368.

DE FINA, A. (2016). Linguistic Practices and Transnational Identities. In: Preece, S. (ed.), The Routledge Handbook of Language and Identity. London/New York: Routledge, pp. 163-178.

DE FINA, A. and TSENG, A. (2017). Narrative in the Study of Migrants. In: Canagarajah, S. (ed.), The Routledge Handbook of Migration and Language. London/New York: Routledge, pp. 381-396.

DUCHÊNE, A., MOYER, M. and ROBERTS, C. (2013). Introduction: Recasting Institutions and Work in Multilingual and Transnational Spaces. In: Duchêne, A., Moyer, M. and Roberts, C. (eds.), Language, Migration and Social Inequality: A Critical Sociolinguistic Perspective on Institutions and Work. Bristol: Multilingual Matters, pp. 6-21.

FAIRCLOUGH, N. (2003). Analyzing Discourse: Textual Analysis for Social Research. London: Routledge.

FAIRCLOUGH, N. (1992). Discourse and Social Change. Cambridge: Polity Press.

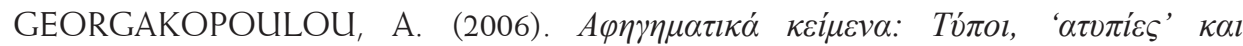
$\pi \rho \alpha \kappa \tau \imath \kappa \varepsilon ́ \varsigma$ [Narrative Texts: Types, 'A-typical Structures' and Practices]. In: Goutsos, D., Koutsoulelou, S., Bakakou-Orfanou, E. and Panaretou, E. (eds.),

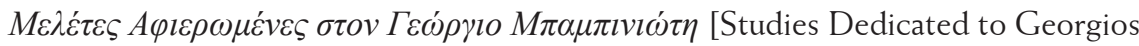
Babiniotis]. Athens: Ellinika Grammata, pp. 33-48.

GEORGAKOPOULOU, A. (2007). Small Stories, Interaction and Identities. Amsterdam/ Philadelphia: John Benjamins.

HANSON-EASY, S. A. and AUGOUSTINOS, M. (2012). Narratives from the Neighborhood: The Discursive Construction of Integration Problems in Talkback Radio. Journal of Sociolinguistics. v. 16, $\mathrm{n}^{\circ} 1$, pp. 28-55.

LABOV, W. (1972). Language in the Inner City. Philadelphia: University of Pennsylvania Press. 


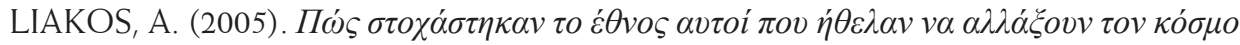
[How Those Who Wanted to Change the World Perceived the Nation]. Athens: Polis.

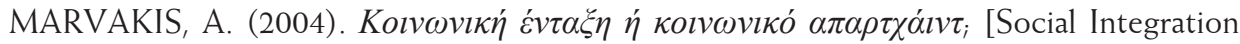
or Social Apartheid?] In: Pavlou, M. and Christopoulos, D. (eds.), H E $\lambda \lambda \dot{\alpha} \delta \alpha \tau \eta \varsigma$

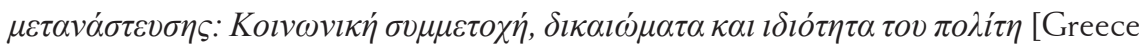
of Migration: Social Participation, Rights and Citizenship, Athens: Kritiki Publishing S.A. and Minority Groups Research Centre, 88-120.

MICHAIL, D. and CHRISTOU, A. (2016). Diasporic Youth Identities of Uncertainty and Hope: Second-generation Albanian Experiences of Transnational Mobility in an Era of Economic Crisis in Greece. Journal of Youth Studies. v. 19, nº 7, pp. 957-972.

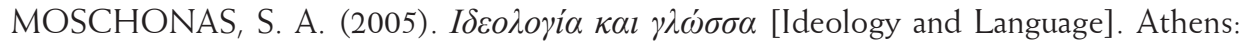
Patakis.

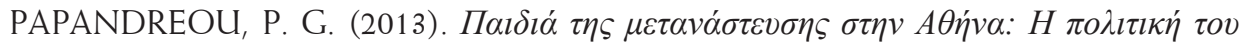

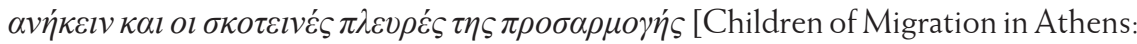
The Politics of Belonging and the Downsides of Adjustment]. Athens: Nissos.

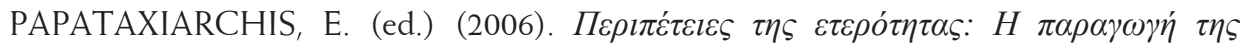

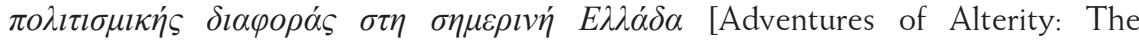
Production of Cultural Difference in Contemporary Greece]. Athens: Alexandria Publications.

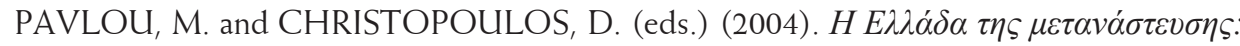

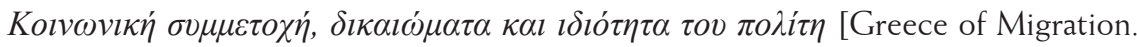
Social Participation, Rights and Citizenship]. Athens: Kritiki Publishing S.A. and Minority Groups Research Centre.

SIFIANOU, M. (2016). On Culture, Face and Politeness. Again. In: BogdanowskaJakubowska, E. (ed.), New Ways to Face and (Im)Politeness. Katowice: Wydawnictwo Uniwersytetu Śląskiego, pp. 15-30.

SIFIANOU, M. and BAYRAKTAROĞLU, A. (2012). 'Face', Stereotyping, and Claims of Power: The Greeks and Turks in Interaction. In: Paulston, C. B., Kiesling, S. F. and Rangel, E. S. (eds.), The Handbook of Intercultural Discourse and Communication. Oxford: Wiley-Blackwell, pp. 292-312. 
SPENCER-OATEY, H. (2005). (Im)politeness, Face and Perceptions of Rapport: Unpackaging Their Bases and Interrelationships. Journal of Politeness Research. $\mathrm{n}^{\circ} 1, \mathrm{pp}$. 95-119.

TSOKALIDOU, P. (2017). SiDaYes! Пé $\rho \alpha \alpha \pi o ́ ~ \tau \eta ~ \delta l \gamma \lambda \omega \sigma \sigma i \alpha ~ \pi \rho o \varsigma ~ \tau \eta ~ \delta \imath \alpha \gamma \lambda \omega \sigma \sigma ı \kappa o ́ \tau \eta \tau \alpha:$ Beyond Bilingualism to Translanguaging. Athens: Gutenberg.

VAN DIJK, T. A. (1992). Discourse and the Denial of Racism. Discourse and Society. v. 3, nº 1, pp. $87-118$.

VAN DIJK, T. A. (2005). Racism and Discourse in Spain and Latin America. Amsterdam/ Philadelphia: John Benjamins.

VAN DIJK, T. A. (2008). Discourse and Power. New York: Palgrave Macmillan.

WODAK, R. and RICHARDSON, J. E. (eds.) (2013). Analyzing Fascist Discourse: European Fascism in Talk and Text. London: Routledge.

Recebido: 22/8/2020

Aceito: 11/10/2020

Publicado: 13/10/2020 